\title{
River reveals chilling tracks of ancient flood
}

A thousand years after the last ice age ended, the Northern Hemisphere was plunged back into glacial conditions. For 20 years, scientists have blamed a vast flood of meltwater for causing this 'Younger Dryas' cooling, 13,000 years ago. Picking through evidence from Canada's Mackenzie River, geologists now believe they have found traces of this flood, revealing that cold water from North America's dwindling ice sheet poured into the Arctic Ocean, from where it ultimately disrupted climate-warming currents in the Atlantic.

The researchers scoured tumbled boulders and gravel terraces along the Mackenzie River for signs of the meltwater's passage. The flood "would solve a big problem if it actually happened”, says oceanographer Wally Broecker of Columbia University's Lamont-Doherty Earth Observatory in Palisades, New York, who was not part of the team.

On page 740 , the geologists present evidence confirming that the flood occurred (J. B. Murton et al. Nature 464, 740-743; 2010). But their findings raise questions about exactly how the flood chilled the planet. Many researchers thought the water would have poured down what is now the St Lawrence River into the North Atlantic Ocean, where the currents form a sensitive climate trigger. Instead, the Mackenzie River route would have funnelled the flood into the Arctic Ocean (see map).

The Younger Dryas was named after the Arctic wild flower Dryas octopetala that spread across Scandinavia as the big chill set in. At its onset, temperatures in northern
Europe suddenly dropped $10^{\circ} \mathrm{C}$ or more in decades, and tundra replaced the forest that had been regaining its hold on the land. Broecker suggested in 1989 that the rapid climate shift was caused by a slowdown of surface currents in the Atlantic Ocean, which carry warm water north from the Equator to high latitudes (W. S. Broecker et al. Nature 341, 318-321; 1989). The currents are part of the 'thermohaline' ocean circulation, which is driven as the cold and salty - hence dense - waters of the far North Atlantic sink, drawing warmer surface waters north.

Broecker proposed that the circulation was disrupted by a surge of fresh water that overflowed from Lake Agassiz, a vast meltwater reservoir that had accumulated behind the retreating Laurentide Ice Sheet

"There's no way for that water to go out of the Arctic without going into the Atlantic."

features there suggest that the region had two major glacial outburst floods, the first of which coincides with the onset of the Younger Dryas. If the western margins of the Laurentide Ice Sheet lay just slightly east of their assumed location, several thousand cubic kilometres of water would have been able to flood into the Arctic Ocean.

"Geomorphic observations and chronology clearly indicate a northwestern flood route down the Mackenzie valley," says James Teller, a geologist at the University of Manitoba in Winnipeg, Canada, who took part in the study. But he thinks that the route raises questions about the climatic effects of the Lake Agassiz spill. "We're pretty sure that the water, had it flooded the northern Atlantic, would have been capable of slowing the thermohaline ocean circulation in the area of today's Great Lakes. The fresh water would have reduced the salinity of the surface waters, stopping them from sinking.

The theory is widely accepted. However, scientists never found geological evidence of the assumed flood pathway down the St Lawrence River into the North Atlantic; or along a possible alternative route southwards through the Mississippi basin. Now it is clear why: the flood did occur; it just took a different route.

The team, led by Julian Murton of the University of Sussex in Brighton, UK, dated sand, gravel and boulders from eroded surfaces in the Athabasca Valley and the Mackenzie River delta in northwestern Canada. The shapes of the geological and produce the Younger Dryas cooling," he says. "The question is whether it could have done the same in the Arctic Ocean."

Broecker, however, says that the Arctic flood is just what his theory needed. He says that flood waters heading down the St Lawrence River might not have affected the thermohaline circulation anyway, because the sinking takes place far to the north, near Greenland. A pulse of fresh water into the Arctic, however, would ultimately have flowed into the North Atlantic and pulled the climate trigger there. "There's no way for that water to go out of the Arctic without going into the Atlantic," he says. Quirin Schiermeier, with additional reporting by Richard Monastersky

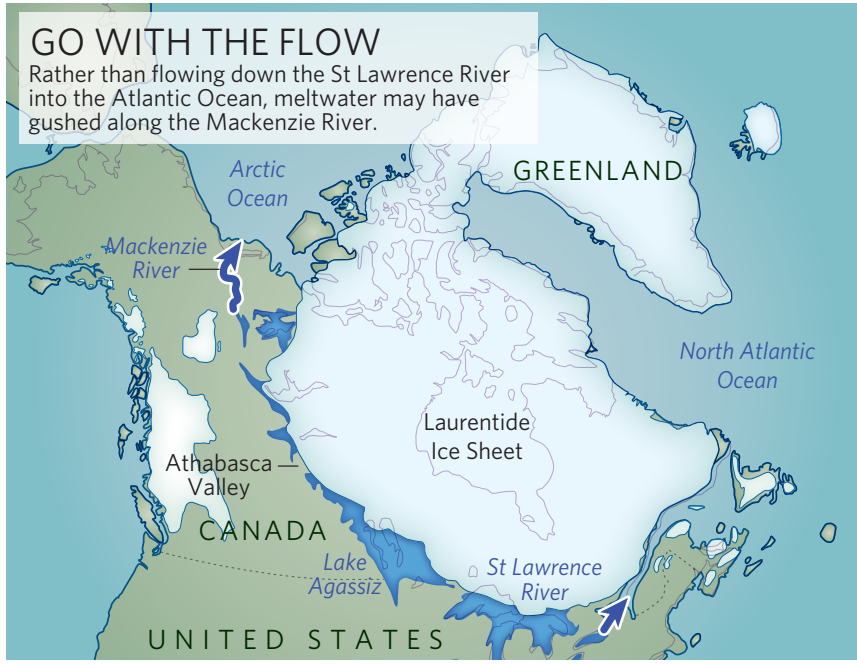

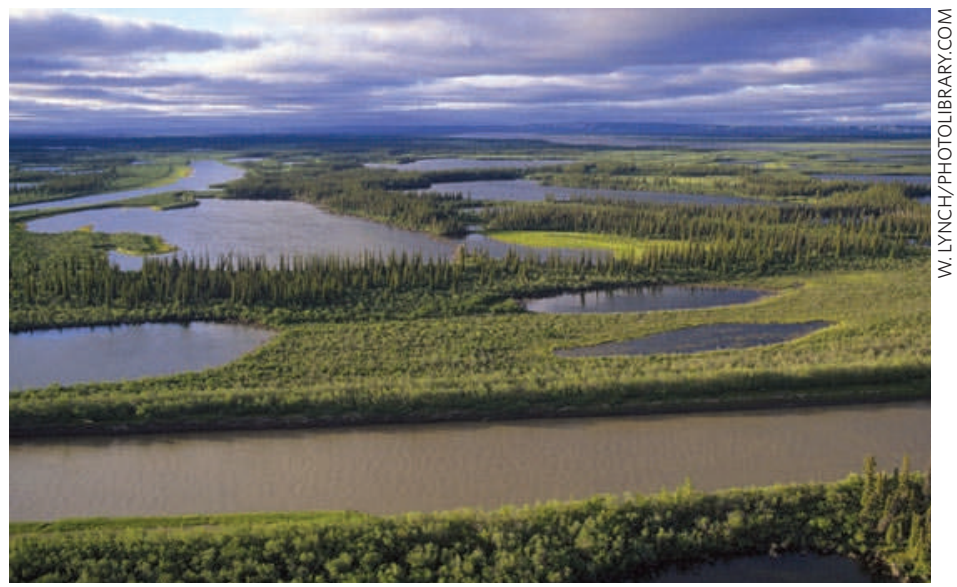

The Younger Dryas flood 13,000 years ago could have emptied into the Arctic Ocean through the Mackenzie River delta (above). 